\title{
Insights into the Pathogenesis and Genetic Background of Patency of the Ductus Arteriosus
}

\author{
Regina Bökenkamp ${ }^{a}$ Marco C. DeRuiter ${ }^{b}$ Conny van Munsteren ${ }^{b}$ \\ Adriana C. Gittenberger-de Groot ${ }^{\mathrm{b}}$ \\ Departments of ${ }^{\mathrm{a}}$ Pediatric Cardiology and ${ }^{\mathrm{b}}$ Anatomy and Embryology, Leiden University Medical Center, \\ Leiden, The Netherlands
}

\section{Key Words}

Ductus arteriosus - Ductus arteriosus regulation, animal models $\cdot$ Ductus arteriosus remodeling, animal models · Persistent ductus arteriosus, syndromic/non-syndromic • Vascular smooth muscle cells

\begin{abstract}
The unique differentiation program of the ductus arteriosus (DA) is essential for its specific task during fetal life and for the adapting circulation after birth. Phenotypic changes occur in the DA during the normal maturation and definitive closure. Morphological abnormalities of the vessel wall characterize the persistent DA (PDA) in older children. Here, we give an overview of the animal models of DA regulation and remodeling. Genetic research has identified the cause of syndromic forms of PDA, such as the TFAP $2 B$ mutations in Char syndrome. Genes that interfere with the remodeling of vascular smooth muscle cells (VSMCs) of the ductal media are affected in virtually all of these anomalies. Therefore, the pivotal regulatory role of VSMCs is emphasized. A better understanding of the genetic background of this developmental process may help develop new strategies to manipulate the DA in premature infants, neonates with duct-dependent anomalies, and patients with syndromic and non-syndromic PDA.

Copyright $\odot 2009$ S. Karger AG, Basel
\end{abstract}

\section{Introduction}

Reflecting the increased survival of premature infants, the prevalence of patent ductus arteriosus (DA) has risen to $13.5 \%$ of all heart defects present at birth [1]. In clinical practice, the expression patent DA is often used synonymously with persistent DA. Both are abbreviated as 'PDA', although they differ in morphology [2,3] and therapeutic implications. In this review, we will use the abbreviation PDA to refer to persistent DA.

The term 'patent DA' is an umbrella term for all situations in which the DA is open either physiologically or pathologically. In healthy premature infants of 30-37 gestational weeks, spontaneous closure of the DA is documented by echocardiography in $50-58 \%$ of infants on the second and $81-87 \%$ of infants on the third day of life [4]. In $90 \%$ of healthy term babies, the DA is functionally closed by $72 \mathrm{~h}$ of life [5]. Term infants with respiratory failure show a significant delay in ductal closure within the first $24 \mathrm{~h}$ of life [6] and sometimes suffer from a hemodynamically significant patent DA that requires treatment [7]. Causes for the prolonged patency of the DA can be structural, as well as functional, immaturity and altered physiological conditions. Targeted deletions of genes that are essential in the physiological closing process have produced animal models of patent DA.

\section{KARGER}

Fax +41613061234 E-Mail karger@karger.ch www.karger.com
Adriana C. Gittenberger-de Groot, $\mathrm{PhD}$

Department of Anatomy and Embryology, Leiden University Medical Center Postal Zone S1-P, PO Box 9600

NL-2300 RC Leiden (The Netherlands)

Tel. +31 71526 9305, Fax +31 71526 8289, E-Mail acgitten@lumc.nl 
PDA in older children (beyond 3 months after full gestation) is histologically characterized by an abnormal high amount of elastin and the presence of a subendothelial elastic lamina [2]. Variants of PDA have also been documented in adult animals $[8,9]$. PDA should be distinguished from the immature but normally developed patent DA in premature and young infants and must be considered as a primary congenital malformation of the vessel wall [2]. Because it usually occurs sporadically, PDA has not been regarded as a typical genetic disorder. Nonetheless, PDA occurs in 5\% of siblings of PDA cases [10], suggesting a genetic component to the pathogenesis, which has typically been presumed to be multifactorial. Very recently, the contribution of genetic factors to the incidence of patent DA in premature infants has also been documented [11, 12]

Heritable PDA has been described in various animal models $[8,9]$. In humans, $8-11 \%$ of cases with PDA have a chromosomal abnormality $[13,14]$. The search for a functionallink between the genes affected in genetic syndromes associated with PDA may elucidate the complex interactions between mutations and modifier genes as well as between environmental factors and genetic polymorphisms related to PDA and patent DA in premature infants. Serious side effects and therapeutic failure are associated with the present pharmacological approach to the DA targeting on the prostaglandin (PG) pathway. Knowledge of which genes maintain the balance between patency and closure of the DA may help to develop pharmacogenetic strategies tailored to individual genomes in order to improve our therapeutic protocols. In the present paper, human and animal data on DA maturation and remodeling and the genetic background of DA closure and patency are reviewed.

\section{Animal Models}

\section{Physiological Ductal Closure in Animals}

Physiological ductal closure has been studied in various vertebrate species [15]. Most of the data are derived from mammals. Since 2006, there is a growing amount of literature on birds [16-18]. Birds and humans share basic mechanisms of vasoreactivity and response to oxygen at the end of the fetal period. The easy accessibility of the fetal circulation in a chicken egg makes it an attractive model for DA physiological studies [19].

The DA remodels and matures in diverse ways among the different vertebrates, but its origin can be traced back to a specific segment of the sixth pharyngeal arch in all of them. In all species, the fetal DA is a large muscular artery composed of layers of vascular smooth muscle cells (VSMCs) separated by layers of elastin. Figure 1 presents a schematic overview of the morphological appearance of the human DA during maturation and the processes involved in its functional and permanent closure. The characteristic histological features of delayed ductal closure in the premature neonate and the PDA are included in this figure. In larger animals, such as dogs [8], lambs [20], and primates [21], ductal closure is accompanied by intimal cushion formation, which starts during fetal life. Although there is some resemblance in the process of ductal closure between larger animals and humans, the relevance of intimal cushions seems to be different. Humans show the earliest onset of intimal thickening and, by far, the most extensive cushion formation [22]. The DA of small animals, such as rats, rabbits, and mice, show less pronounced intimal thickening. These ducts close functionally within minutes after birth, predominantly by vasoconstriction [15]. The same sequence of structural changes occurs in all species: (1) endothelial detachment from the internal elastic lamina (IEL); (2) subendothelial accumulation of the extracellular matrix; (3) migration of VSMCs through a fragmented IEL; (4) occlusion of the lumen by the thickened intima, and (5) degeneration of the DA into a fibrous remnant [15]. In larger [8] as well as smaller [16] animal models, the process proceeds from the pulmonary to the aortic end of the DA. Anatomic remodeling and permanent closure of the DA require the environmental and physiological changes related to birth and air breathing. For instance, intense hypoxia within the constricted vessel wall of the DA at birth is a trigger for VSMCs to express vascular endothelial cell growth factor (VEGF) [21, 23]. VEGF stimulates neointima proliferation and vasa vasorum ingrowth, thereby playing a role during permanent DA closure in lambs and baboons and probably also in humans [24]. These interactions between functional and morphological changes in the DA inspired us to include all aspects of fetal regulation and of physiological and anatomical DA closure in one figure (fig. 2).

\section{Physiology and Pharmacology of Constriction and Relaxation}

For decades, the constrictive effect of oxygen on the DA in the neonate [25] as well as the relaxing effect of $\mathrm{PGE}_{2}$ [26] have been shown. Studies in various animal species and in vitro models revealed additional mediators for DA regulation and remodeling. Species differences in the degree, timing, and type of reaction to the stimuli 
Legends
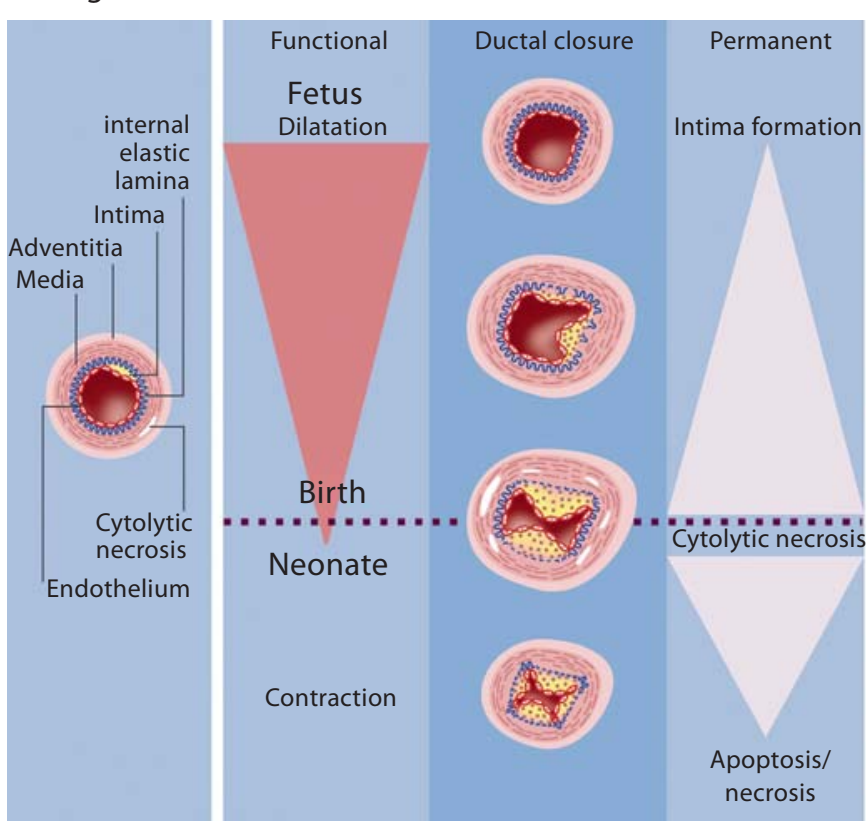

Fig. 1. Schematic overview of the processes related to functional and anatomical closure in the human DA. Normal: During intrauterine life, the ductus remains in a dilated state. Functional closure after birth is achieved by immediate contraction of the ductus. Postnatal occlusion of the lumen and anatomical closure is facilitated by the development of intimal cushions, completely obliterating the lumen in the mature ductus. The ductus finally
Premature

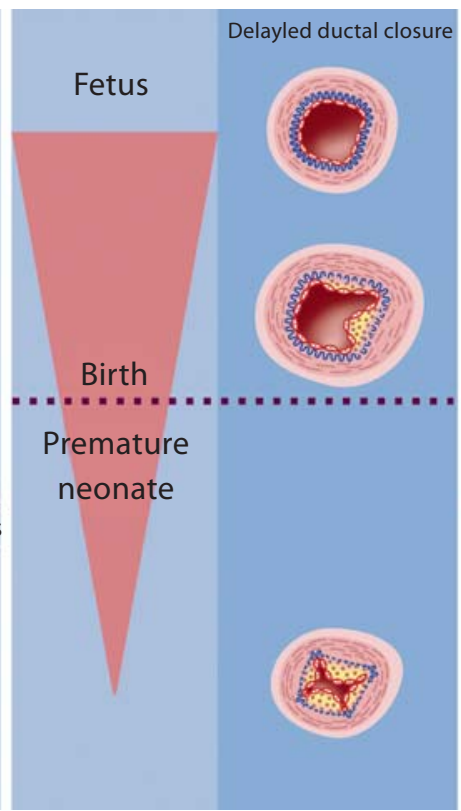

PDA $>3$ months

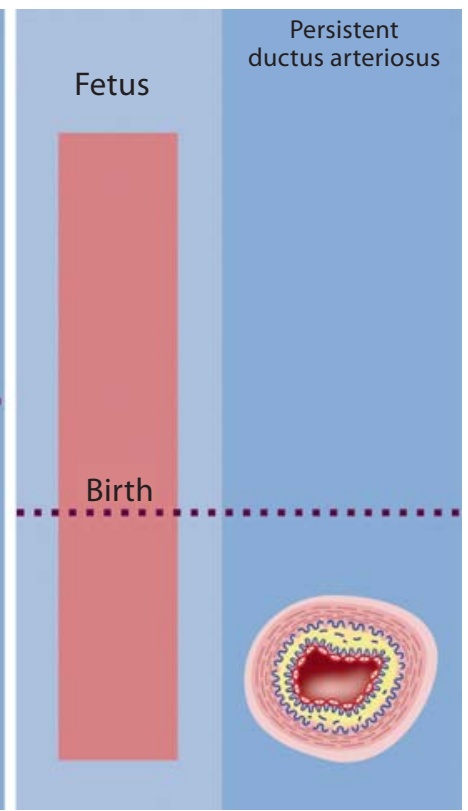

degenerates into a fibrous remnant through apoptosis and necrosis. The histological maturity stages are derived from Gittenberger-de Groot et al. [22]. Premature: The delayed closure of the DA in premature neonates with poorly developed intimal cushions. PDA >3 months: Schematic representation of the PDA of older children, which is characterized by an additional subendothelial elastic lamina and less-developed, elastin-rich intimal cushions.

ductus, COX1 has a predominant role during gestation [30]. Exposure in utero to COX inhibitors, such as indomethacin, can result in premature closure of the DA [31]. Conversely, an increase of the incidence of symptomatic patent DA in infants of mothers who received indomethacin tocolysis has also been observed [32]. These contradictory observations suggest a more complex role for PGs in the developmentally regulated process of DA maturation and postnatal closure. Several agents sustaining ductal patency in concert with PGs in animal studies do not act in the same way in humans [33]. NO produced mainly via eNOS is a vasorelaxant in the DA [34]. NO acts as an alternative for, and synergizes with, $\mathrm{PGE}_{2}$ [35]. The $\mathrm{NO}$ mechanism is relatively more important in the preterm than in the full-term ductus [36] and can compensate for PG-induced relaxation when PG biosynthesis is eliminated or inhibited by drugs $[37,38]$. In their in vitro and in vivo studies using wild-type and gene-deleted mice, Baragatti et al. [35] described $\mathrm{NO}$ and $\mathrm{CO}$ as being cooperative mediators of bradykinin-induced relaxation in the absence of $\mathrm{PGE}_{2}$. In the absence of all three agents 


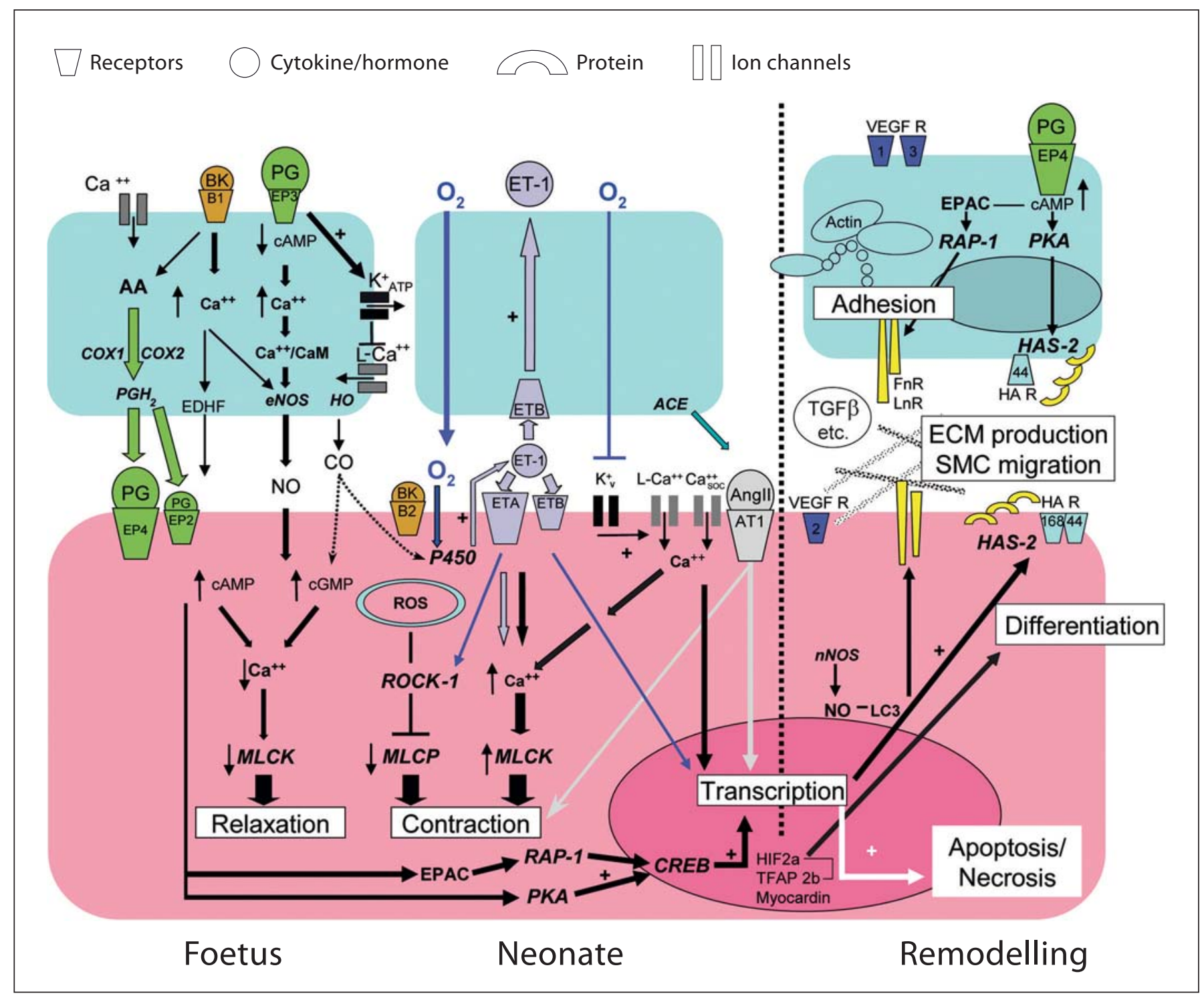

Fig. 2. Diagram of the experimental data on intracellular and intercellular signaling related to ductus closure and remodeling that is presented in this review. ECs are depicted in light blue. VSMCs are indicated by the large pink rectangle. For the sake of clarity, not all downstream signaling steps are included. On the left side, the dominant signaling pathways in the fetus are shown. The middle section illustrates the changes related to the increase of oxygen saturation at birth. The section to the right of the vertical dotted line focuses on anatomical remodeling. Remodeling proceeds through a sequence of events including the differentiation of VSMCs and ECs, extracellular matrix production, SMC migration, and finally apoptosis and necrosis. Abbreviations: $\mathrm{AA}=\mathrm{Ar}$ achidonic acid; ACE = angiotensin-converting enzyme; Ang II = angiotensin II with AT1 receptor; $\mathrm{BK}=$ bradykinin with receptors $\mathrm{B} 1$ and $\mathrm{B} 2 ; \mathrm{Ca}^{++}=$calcium ion and channels: $\mathrm{Ca}_{\text {soc }}^{++}=$store-operated; $\mathrm{L}-\mathrm{Ca}^{++}=$voltage-dependent; $\mathrm{CaM}=$ calmodulin; $\mathrm{cAMP}=$ cyclic adenosine monophosphate; $c \mathrm{GMP}=$ cyclic guanosine monophosphate; $\mathrm{CO}=$ carbon monoxide; $\mathrm{COX}=$ cycloxygenase isoforms 1 and 2; CREB = cAMP response element-binding protein;
$\mathrm{ECM}=$ extracellular matrix; EDHF = endothelium hyperpolarizing factor; EPAC = exchange proteins activated by cAMP; ET1 = endothelin-1 with ET-A and ET-B receptors; HAS- 2 = hyaluronan synthase-2; FnR = fibronectin receptor; HA hyaluronic acid receptors; CD44 and CD168 = receptors for hyaluronic acidmediated motility; HIF-2a = hypoxia-inducible factor- $2 \alpha$; $\mathrm{HO}=$ hemoxygenase; $\mathrm{K}^{+}=$potassium ion and channels: $\mathrm{K}_{\mathrm{ATP}}=\mathrm{ATP}-$ sensitive channel; $\mathrm{K}_{\mathrm{v}}=$ voltage-gated channel; $\mathrm{LC} 3=$ microtubule-associated protein; $\mathrm{LnR}=$ laminin receptor; $\mathrm{MLCK}=$ myosin light-chain kinase; MLCP = myosin light chain phosphatase; $\mathrm{NO}=$ nitric oxide; $\mathrm{NOS}=$ nitric oxide synthase isoforms (endothelial) eNOS and (neuronal) nNOS; $\mathrm{PGH}_{2}=$ prostaglandin $\mathrm{H}_{2}$; $\mathrm{PG}=$ prostaglandins, predominantly $\mathrm{PGE}_{2}$ acting via prostaglandin receptors $(\mathrm{EP} 2,3,4) ; \mathrm{PKA}=$ protein kinase $\mathrm{A}$; $\mathrm{RAP} 1=$ small RAS-like GTPase acting downstream of EPAC; ROCK-1 = rho-associated, coiled-coil-containing protein kinase 1 ; $\mathrm{ROS}=$ reactive oxygen species; TFAP2B = transcription-factor-activating protein-2 $\beta$; VEGF = vascular endothelial growth factor. 
( $\mathrm{PGE}_{2}, \mathrm{NO}$ and $\left.\mathrm{CO}\right)$, bradykinin induces a relaxant substance that behaves like endothelium-derived hyperpolarizing factor.

Although there are interspecies differences in timing, the rise in blood oxygen tension with the start of respiration is critical for early (functional) closure of the ductus [25]. The contraction in response to oxygen is intrinsic to VSMCs of the ductus and is highly conserved. Ion channels and other vasoactive systems are involved in the acute ductal constriction immediately after birth. VSMC contraction is regulated by phosphorylation/dephosphorylation of myosin light chains (MLCs). Inhibition of myosin light chain phosphatase (MLCP) and activation of the calcium/calmodulin-dependent myosin light chain kinase (MLCK) both increase phosphorylation and thereby facilitate myosin/actin interaction and contraction. Kajimoto et al. [39] recently determined that rho-kinase (ROCK) activation by $\mathrm{O}_{2}$ in the DA (but not in other fetal arteries) involves a redox-dependent activation of ROCK1. They concluded that the DA had a relatively unique ability of increasing endogenous $\mathrm{H}_{2} \mathrm{O}_{2}$ in response to increased $\mathrm{PO}_{2}$ and proposed a temporal sequence of $\mathrm{O}_{2}$ constriction in three phases: (1) an early electrical phase that involves $K_{v}$ channel inhibition, membrane depolarization, and activation of the L-type, voltage-gated calcium channel; (2) a mediator phase that involves increased endothelin (ET-1) synthesis, and (3) a calcium-sensitization phase that involves the activation of ROCK. In the neonate, the increased arterial $\mathrm{O}_{2}$ concentration inhibits voltage-gated potassium channels $\left(\mathrm{K}_{\mathrm{v}}\right)$ and promotes calcium entry via L-type calcium channels [40, 41]. Oxygen sensing takes place in the proximal electron transport chain in the mitochondrion and is mediated by ROS $\left(\mathrm{H}_{2} \mathrm{O}_{2}\right)$ [33]. The cytochrome $\mathrm{P} 450$ heme protein in the plasma membrane of the VSMCs has been previously suggested as a receptor for oxygen-induced events [42].

The potent vasoconstrictor ET-1 is produced by ECs and VSMCs in the DA [42] and interacts with both endothelin receptors (ETA and ETB). In vitro, ET-1 is released in response to increased oxygen levels, which may be sensed by cytochrome P450 [42, 43]. The role of ET- 1 in vivo is less clear and probably varies between different species. An ETA receptor blockade in lambs does not impair ductal constriction [44]. In fetal rats [45], ET-receptor blockade prevents constriction of the DA by cyclooxygenase inhibitors. The DA in ETA receptor-deleted mice closes postnatally, but the acute vasoconstrictor response to oxygen is attenuated [46]. This may reflect the disruption of a normal reinforcing effect of ET-1 on voltage-gated potassium channels [47] or the $\mathrm{IP}_{3}$-dependent release of intracellular calcium [39]. Calcium-sensitization pathways have been documented in rabbits and humans [48]. Store-operated calcium channels [48] act as additional components of normoxic contraction. Functional immaturity of calcium-dependent and calciumsensitization pathways [48] during the hypoxic phase of remodeling might explain why the DA in prematures tends not to stay tightly closed. Gene expression data [49] show an upregulation of the angiotensin receptor gene (AGTR1) in neonatal rats. Therefore, angiotensin II has also been suggested to be a vasoconstrictive effector.

\section{PDA in Animals}

\section{PDA in Dogs}

Most cardiac malformations known to man are also observed with a similar prevalence in dogs $(5-8 / 1,000)$. In 1982, Helen Taussig [50] described that several of these malformations are heritable in specific breeds of dogs (PDA, pulmonary stenosis, and subaortic stenosis), rabbits (vestigial pulmonary artery), and rats (ventricular septal defect). The fact that these malformations occur in various animals that cannot interbreed made her conclude that the deoxyribonucleic acid (DNA) that codes for these malformations must lie in a portion of DNA that is common to all mammals and, therefore, may be genetic variants of cardiac development [50].

PDA is the most common cardiac anomaly in dogs [51]. An animal model of inherited PDA has been studied in dogs by Patterson et al. [52], and the pathomorphology has been described [8]. Histological features of the normal DA and PDA in this strain of dogs resemble those of the normal DA and PDA in humans, suggesting a similar pathogenesis in both species. Immunohistochemical data from this dog model suggest a role for prostacyclin $\left(\mathrm{PGI}_{2}\right)$ in the process of intimal thickening. The distribution of $\mathrm{PGI}_{2}$ synthase is identical in all permanently patent vessels [53]. PDA, aorta, and pulmonary artery show high $\mathrm{PGI}_{2}$ synthase expression in the endothelium and low expression in VSMCs. In the normal closing DA of these dogs, however, high amounts of $\mathrm{PGI}_{2}$ and no $\mathrm{PGE}_{2}$ or PG dehydrogenase activity were found in the VSMCs of the intimal cushions [53].

\section{PDA in Rats}

Brown Norway Rat

In a morphological study [9], we previously described hereditary PDA in a specific rat inbred strain - the Brown Norway (BN) rat. The PDA in $\mathrm{BN}$ rats shows abundant 
elastic lamellae in the intima, a subendothelial elastic lamina, and failure of intimal SMC proliferation. These histological features are also hallmarks of human and canine PDA $[2,8]$. In the media of the BN ductus, the elastic lamellae are virtually absent. The aortic media shows impaired elastic lamellae [54], with ruptures in the IEL [55]. This phenotype has been related to the increased vascular fragility that is characteristic of the $\mathrm{BN}$ rat [55]. In PDA, the subendothelial elastic lamina is thought to limit the access of the VSMCs from the media to the intima. There is also strong evidence that intimal cells arise both during development and under pathologic conditions from delamination of ECs [56] and their circulating precursors [57]. Endothelial-mesenchymal transformation has also been described during arteriogenesis in the embryo [58]. Because ECs can also produce elastic laminae, the abundant elastic lamellae in the intima in the PDA support the idea that the intimal-mesenchymal cells are also endothelially derived.

Linkage studies revealed different loci for elastic lamellar anomalies and PDA in BN rats. In a backcross between $\mathrm{BN}$ and the LOU reference strain, the phenotype of a ruptured IEL in the abdominal aorta and the iliac artery showed a highly significant linkage to chromosome 5 and a suggestive linkage to chromosome 10 in BN rats [59]. In the same population, Kota et al. [59] linked $\mathrm{PDA}$ in $\mathrm{BN}$ rats to two different loci on chromosomes 8 and 9.

Adult $\mathrm{BN}$ rats exhibit phenotypic variations in their DA morphology. Unlike other rat strains, a normal ductus ligament is only present in $14 \%$ of the rats [59] $(20 \%$ in our own observations; unpubl. data). In the remaining $86 \%$ of BN rats, variations between grossly visible ductus ligaments and a PDA are found. These variations point to a polygenic control of normal ductal closure. Our own crossing studies in BN/Wistar rats showed one PDA (2.4\%) in the $\mathrm{F}_{2}$ generation and thick ligaments in 41 and $43 \%$ of the rats in the $\mathrm{F}_{1}$ and $\mathrm{F}_{2}$ generations, respectively. In $59 \%$ of the rats in the $F_{1}$ and $57 \%$ in the rats of the $F_{2}$ generation, the ligament was thin, as seen in Wistar rats. These findings are comparable to the results of the crossing experiments reported by Kota et al. [59] in BN/LOU backcross rats, in which only $3.7 \%$ of rats had a macroscopically visible ductus with a widely patent aortic and stenosed pulmonary end.

\section{Gene-Targeted Mice}

Gene-targeted mice have been created in order to elucidate mechanisms by which known effectors affect ductus development, prenatal patency, and postnatal ductal closure. Mice carrying deletions of components of the PG pathway, the ET-1 receptor, and other genes interfering with VSMC differentiation will be discussed in the following section.

Mouse Models with Deletions in the PG Pathway

Targeted deletions that reduce the $\mathrm{PGE}_{2}$ production or function paradoxically do not affect the prenatal ductal patency [60-62] but instead may result in impaired DA closure after birth [61-62]. Although the importance of $\mathrm{PGE}_{2}$ signaling for postnatal DA closure has been known from EP4-deleted and COX-deleted animals for a long time, the explanation for this paradoxical behavior has only recently been elucidated by Yokoyama et al. [63]. In their study, they were able to document that $\mathrm{PGE}_{2}$ binding to the EP4 receptor results in intimal cushion formation via the $\mathrm{CAMP} /$ protein kinase $\mathrm{A}$ (PKA) pathway. PKA mediates the direct vasodilating effect of $\mathrm{PGE}_{2}$ by inhibiting MLCK. Furthermore, PKA and exchange proteins activated by cAMP (EPAC1), a newly identified effector CAMP, promote hyaluronic acid production by hyaluronic acid synthase 2 (HAS2) activation. Subendothelial hyaluronic acid accumulation induces the formation of intimal cushions, which are required for DA closure (see fig. 2).

As cyclooxygenase-peroxidases, COX1 and COX 2 catalyze the synthesis of $\mathrm{PGH}_{2}$, which is the precursor of biologically active PGs. When looking at the COX-deleted mice in detail, COX2 seems to be more important for DA closure than COX1. Trivedi et al. [64] were the first to emphasize that COX2 has a vital role for ductal closure after term birth and is attenuated in preterm gestation. In addition to the COX2 effect, a gene dosage-dependent effect of COX1 has been documented [61,65]. Two groups $[61,66]$ have described contrasting results concerning the impact of individual COX isoform ablation on the postnatal closure of the DA in mice. Baragatti et al. [66] documented no genotype-related difference in postnatal closure of the DA in COX-deleted mice born after vaginal delivery, while Loftin et al. [61] described mortality due to patent DA in $35 \%$ of $\operatorname{COX} 2(-/-)$ mice and $100 \%$ of mice deficient for both isoforms. The absence of the COX1 isoform did not affect DA closure in the experimental setting of Loftin et al. [61] who studied the mice after a cesarean section at gestational day 19.5. The mortality (35\%) and incidence of patent DA due to the absence of COX2 is, however, significantly increased (79\%) when one copy of the gene encoding COX1 is also inactivated. When comparing the phenotypes of the COX2-deficient mice with a model of selective genetic 
COX2 inhibition that leaves its peroxidase activity intact, Yu and Funk [65] surprisingly found no abnormalities in ductal remodeling after birth. These findings might imply that a COX1/2 heterodimer is involved in signaling in the ductus [67]. Interestingly, there is also interplay between EP4 receptor activation and COX2 expression. The experiments of Trivedi et al. [64] indicate that the genetic deficiency of EP4 results in attenuated COX2 expression.

In the late 1990s, Ngyuen et al. [62] and Segi et al. [68] both generated EP4 receptor knockout (KO) mice and described the same phenotype. They found that the loss of the EP4 receptor is not lethal in utero but causes $95 \%$ mortality within $72 \mathrm{~h}$ after delivery due to congestive heart failure. Histological examination confirmed ductal patency. In the remaining 5\% of EP4(-/-) mice, the ductus was either closed or severely narrowed. The animals were fertile and survived for more than a year [68]. Ngyuen et al. [62] were able to show that selective breeding of the survivors increased the survival rate among EP4(-/-) mice to $21 \%$, suggesting that other alleles on other loci can provide an alternative to EP4.

\section{ET-1 Receptor KO Mice}

Mice lacking the ET-1 receptor ETA are described by Coceani et al. [46]. These mice showed a discrepant behavior of the ductus in vivo and in vitro. Isolated DA from ETA-/- mice contracted marginally to oxygen and ET-1 but responded to a thromboxane analogue. In normoxic newborn mice, reduction in the ductus lumen was equally pronounced in $-/-$ and $+/+$ littermates. Conversely, no such narrowing was seen in hyperoxic -/- fetuses, although it did occur in $+/+$ littermates. No genotype-related difference was noted in the morphology of the ductus. These data indicated that ET-1 mediates the ductus constriction in response to oxygen but is not critical for postnatal ductus closure.

\section{Smooth Muscle Myosin Heavy Chain (SM-MHC) KO Mice}

Proper regulation of VSMC contraction in response to the postnatal rise of oxygen tension is necessary for functional ductal closure. The observation of delayed (6-12 $\mathrm{h}$ post-partum) but not failed closure of the DA in SMMHC KO mice suggests that ductal VSMC contractions can be generated partly (phase 2 or sustained state of contraction) by activation of the non-muscle myosin heavy chain (NM-MHC), as documented for intact bladder preparations from the same mice. The ability to recruit two distinct contractile systems, namely SM myosin for phasic contraction and non-muscle (NM) myosin during prolonged tonic contraction, can explain the unique properties of VSMCs during prolonged activation [69].

Transcription Factor AP2 Beta (TFAP2B) KO Mice

Targeted deletion of TFAP2B, a neural crest-enriched transcription factor, causes apoptosis of renal epithelial cells and postnatal death, possibly related to polycystic kidney disease [70]. Ivey et al. [71] did not observe morphological differences between the TFAP2B-/- and wildtype mice that were studied beyond mid-gestation at embryonic days 13.5, 15.5 and 18.5. Data on postnatal ductal behavior and morphology in TFAP2B-/- mice are not included in their paper. Preferential calponin expression, which characterizes the advanced maturation and differentiation of ductal SMCs in wild-type mice, was lost in TFAP2B-/- mice by embryonic day 18.5. These data indicate that TFAP2B disruption affects the development of VSMCs within the DA. Abnormal maturation of ductal SMCs may contribute to delayed ductal closure in TFAP2B-/- mice and PDA in humans with Char syndrome.

Selective Ablation of the Myocardin Gene in Neural Crest-Derived VSMCs

Myocardin regulates the expression of genes required for the contractile phenotype of neural crest-derived VSMCs. Mice generated after selective myocardin ablation of cardiac neural crest-derived VSMCs were symptomatic for a patent DA and died at postnatal day 3. The vascular phenotype of the ductus exhibited ultrastructural and immunohistochemic features that are generally associated with a synthetic rather than a contractile VSMC phenotype [72]. In the mutant mice, the architecture of the intima and media was markedly disorganized, showing a dramatic increase of extracellular matrix and a relative loss of VSMC volume. Relatively few myofibers and a marked increase in synthetic organelles were documented by electron microscopy.

\section{Gene Transfer Experiments}

In vitro gene transfer experiments were carried out in order to study the maturational increase of $\mathrm{O}_{2}$-sensitive, voltage-gated potassium $\left(\mathrm{K}_{\mathrm{v}}\right)$ channels. Transmural $\mathrm{K}_{\mathrm{v}} 1.5$ or $\mathrm{K}_{\mathrm{v}} 2.1$ gene transfer 'rescued' the developmental deficiency in $\mathrm{K}_{\mathrm{v}}$, conferring $\mathrm{O}_{2}$ responsiveness to preterm rabbits. Targeted $S M C K_{v} 1.5$ gene transfer also enhanced $\mathrm{O}_{2}$ constriction in human DA [73].

Gene transfer strategies were also evaluated as a potential substitute for systemic PG administration in neo- 
nates with ductus-dependent circulations. In lambs, gene transfer is feasible and can be used to bioengineer a patent ductus. Mason et al. [74] were able to restrain VSMC migration and intima formation in the ductus by inhibiting fibronectin translation. More recently, Humpl et al. [75] achieved prolonged postnatal ductal patency by transfecting human PG synthase into the vessel wall of the ductus of newborn lambs.

\section{PDA as Part of a Clinical Syndrome in Humans}

PDA is described as part of the spectrum of cardiovascular anomalies in various genetic syndromes. Between 28 and $88 \%$ of PDA cases have other cardiac or non-cardiac defects, and $8-11 \%$ of cases with PDA have chromosomal abnormalities $[13,14]$. In the clinical pediatric literature, the association of isolated PDA with Down's syndrome (4\% of all associated congenital cardiac defects), CHARGE syndrome [76], Cri-du-chat syndrome [77], Noonan syndrome (2.2\% of all associated congenital cardiac defects) [78], and Holt-Oram syndrome [79] is well described. Insight into the cellular mechanisms underlying the phenotypes of these syndromic anomalies is increasing. Even now, a ductus-specific molecular mechanism cannot be derived from a particular syndrome. The most consistent association of PDA with mild dysmorphic features has been found in Char syndrome.

Char syndrome is a more recently described genetic syndrome consisting of PDA in association with facial anomalies and minor skeletal anomalies and is caused by mutations in the transcription factor TFAP2B, which is expressed in neural crest cells [80]. Multiple dominant negative mutations have been documented. Interestingly, genotype-phenotype correlations have been documented for mutations in the basic DNA binding domain and the transactivation domain of TFAP2B [81]. A high prevalence of PDA with very mild facial anomalies and no apparent hand anomalies are found among the carriers of the mutation in the transactivation domain. The genotypephenotype correlation in Char families with a distinct phenotype, combining PDA with only very mild facial and no hand anomalies, suggests the existence of TFAP2B coactivators as a cause for ductal tissue specificity [81].

Heritable disorders of connective tissue structures, such as Marfan, Loeys-Dietz, Larsen, and Ehlers-Danlos syndrome [82-85], and mutations in the VSMC contractile proteins $[86,87]$ cause thoracic aortic aneurysms that lead to acute aortic dissections. Although some reports associate PDA or ductal aneurysm with these types of heritable aortic disorders, the present literature does not put particular emphasis on the DA.

Ductal aneurysm is not unanimously defined in the literature. Aneurysms of the DA are described to occur as a complication after surgical or catheter-interventional treatment of a PDA and also as an incidental finding at the aortic end of a spontaneously closed ductus in nonsyndromic patients [88]. Congenital ductal aneurysm may occur during the third trimester of pregnancy [8991] and is characterized by abnormal dilatation of the aortic end of the ductus with a significantly stenosed or completely occluded pulmonary end of the ductus.

New insights into the molecular pathogenesis of Marfan syndrome (MFS) have challenged the definition of this syndrome as a structural connective tissue disorder [92]. MFS is a developmental abnormality with broad and complex effects on the morphogenesis and function of multiple organ systems. Animal data derived from fibrillin-1-deficient mice have shown that increased TGF- $\beta$ signaling contributes to the process of aortic root dilatation in MFS and that TGF- $\beta$ antagonism (achieved by angiotensin II type 1 receptor blockade) may represent a productive treatment strategy. The upregulation of TGF$\beta$ may be a final common pathway for aortic aneurysms in many disease states, such as Loeys-Dietz and non-syndromic thoracic aortic aneurysm/dissection.

Loeys-Dietz syndrome is a combination of altered cardiovascular, craniofacial, neurocognitive, and skeletal development caused by mutations in TGF- $\beta$ receptors 1 and 2 [83]. The cardiovascular anomalies include aortic root aneurysm and aortic tortuosity in all patients. A PDA or ductal aneurysms were reported in $54 \%$ of affected individuals. Considering that in vitro and in vivo data [93-96] document an important role for TGF- $\beta$ during the physiological remodeling process of the DA, it is tempting to speculate that increased TGF- $\beta$ signaling might also be the final common pathway for ductal patency or ductus aneurysms in MFS and Loeys-Dietz syndrome. The recent observation of the failure of ductal closure in mice after selective ablation of the myocardin gene in neural crest-derived VSMCs [72] also points to TGF- $\beta$ signaling, because myocardin is able to participate in the TGF- $\beta_{1}$ pathway through direct interaction with Smad3 to activate SM22a, SM-MHC, and SM- $\alpha$ actin promoters [97].

Data from Zhu et al. [86] and Guo et al. [87] highlight the importance of contractile proteins for the structural integrity of the aorta. Both studies describe a high prevalence of PDA among families with mutations in VSMC contractile proteins. In 2005, Khau van Kien et al. [98] 
documented the association of PDA and familial thoracic aortic aneurysm and dissection (TAAD) in a large French family. Linkage analysis identified 16p12.2-p13.3 as the locus responsible for both TAAD and PDA in this family. Zhu et al. [86] demonstrated that the disease is caused by mutations in the MYH11 gene, affecting the Cterminal coiled-coil region of the SM-MHC, a specific contractile protein of VSMCs.

Cyclic interaction between myosin encoded by MYH11 and $\alpha$-actin encoded by ACTA 2 are required for the contractile force of VSMCs. Guo et al. [87] have shown that missense mutations in the ACTA2 gene are responsible for $14 \%$ of the inherited TAADs. When reviewing the clinical characteristics and the familial segregation of ACTA 2 mutations in 14 families, 6 individuals from 2 families with a mutation altering Arg258 had PDA. The association of PDA and TAADs in families with mutations in two components of the VSMC contractile proteins suggests that unimpaired VSMC contractility is, in addition to its critical role in maintaining the structural integrity of the aorta, a prerequisite for ductal remodeling, which then leads to anatomical ductal closure.

\section{Non-Syndromic PDA}

The contribution of a recessive locus to non-syndromic PDA in the Iranian population has been studied by Mani et al. [99]. The higher prevalence of PDA in Iran (15\%) compared to that in the United States (2-7\%), together with the increased rate of consanguinity (63\%) among PDA cases compared to that in the general Iranian population (25\%), facilitated their approach to the identification of a recessive locus. Using a genomewide linkage analysis in 21 unrelated, consanguineous PDA cases, they implicate a single locus on chromosome $12 \mathrm{q} 24 \mathrm{p}$. Based upon their data, they estimated that this locus contributes to the pathogenesis of one third of the PDA cases in the Iranian population. Furthermore, they suggest a role for this locus in PDA worldwide.

\section{Genetic Predisposition to Patent Ductus Arteriosus in Preterm Infants}

Very recently, two studies $[11,12]$ dealing with the genetic contributions to ductal patency in premature babies have been published. In a quantitative heritability study on premature twins, Bhandari et al. [12] estimated that the genetic factors or the shared environment accounted for $76.1 \%$ of the variance in liability for patent DA. In a cohort of infants $<32$ weeks of gestation, Dagle et al. [11] performed a single nucleotide polymorphism (SNP) analysis. Initially, they identified seven SNPs significantly associated with patent DA. A second analysis pinpointed an association between genetic variations in TFAP2B, tumor necrosis factor receptor-associated factor 1 , and prostacyclin synthase with ductal patency in premature babies.

\section{Conclusion}

The prenatal patency of the DA and its physiological closure are obtained by highly conserved and parallel acting mechanisms. Ductal remodeling requires a specific sequence of events, which includes the differentiation of VSMCs and ECs, extracellular matrix production, VSMC migration, and finally apoptosis and necrosis. Based upon data generated from human genetic syndromes and experimental animals, various genes that either directly or in combination with environmental factors predispose an individual to PDA have been identified. Because genes interfering with the recruitment of medial or with the proliferation, differentiation, migration, or apoptosis of VSMCs are affected in virtually all of the syndromic anomalies associated with PDA, VSMCs can be considered to be a pivotal cellular structure in the pathogenesis of PDA. Because the process of recruitment and differentiation of VSMCs is dependent upon reciprocal signaling between ECs and mesenchymal cells [100], it is reasonable to infer that ECs in the ductus may also contain transcriptional targets or regulators necessary for the differentiation of the adjacent VSMCs. Several 'classical' angiogenic and vasculogenic signaling pathways are involved in ductus development and remodeling. VEGF regulates remodeling during permanent closure [23], PDGF-BB mediates VSMC proliferation [101], and the AGTR1 gene is upregulated in the neonatal ductus. In addition, angiotensin has been suggested as a novel effector of ductus closure [49]. A transcriptional network, including TFAP2B, ET-1, and hypoxia-inducible factor 1, has recently been suggested to act in ductal VSMCs of developing mice [71]. Our own microarray data in rats (unpubl. data) show a significant upregulation of TFAP2B gene expression in ductal VSMCs compared to aortic cells. A PDA in combination with only very mild dysmorphic features in patients with Char syndrome underscores the tissue specificity of TFAP2B mutations. Furthermore, TFAP2B is one of the three genes suggested in a recent study in preterm infants to be asso- 
ciated with persistent patency of the DA [11]. In animal studies, TGF- $\beta$ signaling has also been linked to ductal remodeling [92-94]. The role of TGF- $\beta$ signaling in the molecular regulation of the maturation and anatomical closure of the DA is not yet fully elucidated. The emerging knowledge of clinical syndromes associated with PDA or ductus aneurysms, which are related to mutations in the TGF- $\beta$ signaling cascade, draws further attention to this signaling pathway.
Technological advances in high-throughput genetic screening will facilitate the identification of pathways and genes involved in ductus development and closure. A better understanding of the genetic background of this developmental process can help develop new strategies in order to manipulate the DA in premature infants, neonates with duct-dependent cardiac anomalies, and patients with syndromic and non-syndromic PDA.

\section{References}

1 Morris CD: Epidemiology of congenital heart disease; in Crawford MH, Di Marco JP (eds): Cardiology. London, Mosby, 2001, chapt 7, pp 1.1-1.8.

2 Gittenberger-de Groot AC: Persistent ductus arteriosus: most probably a primary congenital malformation. Br Heart J 1977;39:610618.

-3 Chuaqui B, Piwonka G, Farrú O: The wall in persistent ductus arteriosus (in German). Virchows Arch A Pathol Anat Histol 1977; 372:315-324.

4 Reller MD, Rice MJ, McDonald RW: Review of studies evaluating ductal patency in the premature infant. J Pediatr 1993;122:S59S62.

5 Lim MK, Hanretty K, Houston AB, Lilley S, Murtagh EP: Intermittent ductal patency in healthy newborn infants: demonstration by colour Doppler flow mapping. Arch Dis Child 1992;67:1217-1218.

6 Walther FJ, Benders MJ, Leighton JO: Early changes in the neonatal circulatory transition. J Pediatr 1993;123:625-632.

7 Ly LG, Hawes J, Whyte HE, Teixeira LS, McNamara PJ: The hemodynamically significant ductus arteriosus in critically ill full-term neonates. Two case reports? Neonatology 2007;91:260-265.

-8 Gittenberger-de Groot AC, Strengers JL, Mentink M, Poelmann RE, Patterson DF: Histologic studies on normal and persistent ductus arteriosus in the dog. J Am Coll Cardiol 1985;6:394-404.

-9 Bokenkamp R, Gittenberger-De Groot AC, Van Munsteren CJ, Grauss RW, Ottenkamp J, Deruiter MC: Persistent ductus arteriosus in the Brown Norway inbred rat strain. Pediatr Res 2006;60:407-412.

10 Lamy M, De Grouchy J, Schweisguth O: Genetic and non-genetic factors in the etiology of congenital heart disease: a study of 1188 cases. Am J Hum Genet 1957;9:17-41.

- 11 Dagle JM, Lepp NT, Cooper ME, Schaa KL, Kelsey KJ, Orr KL, Caprau D, Zimmerman CR, Steffen KM, Johnson KJ, Marazita ML, Murray JC: Determination of genetic predisposition to patent ductus arteriosus in preterm infants. Pediatrics 2009;123:11161123 .
12 Bhandari V, Zhou G, Bizzarro MJ, Buhimschi C, Hussain N, Gruen JR, Zhang H: Genetic contribution to patent ductus arteriosus in the premature newborn. Pediatrics 2009; 123:669-673.

13 Ferencz C LC, Correa-Villasenor A, Wilson PD: Patent arterial duct; in Ferencz C LC, Correa-Villasenor A, Wilson PD (eds): Genetic and Environmental Risk Factors of Major Cardiovascular Malformations: The Baltimore-Washington Infant Study 1981-1989. New York, Futura, 1997, pp 285-299.

14 Stoll C, Alembik Y, Roth MP, Dott B, De Geeter B: Risk factors in congenital heart disease. Eur J Epidemiol 1989;5:382-391.

15 Bergwerff M, DeRuiter MC, Gittenberger-de Groot AC: Comparative anatomy and ontogeny of the ductus arteriosus, a vascular outsider. Anat Embryol 1999;200:559-571.

$>16$ Agren P, Cogolludo AL, Kessels CG, PerezVizcaino F, De Mey JG, Blanco CE, Villamor E: Ontogeny of chicken ductus arteriosus response to oxygen and vasoconstrictors. Am J Physiol 2007;292:R485-R496.

17 Van der Sterren S, Agren P, Zoer B, Kessels L, Blanco CE, Villamor E: Morphological and functional alterations of the ductus arteriosus in a chicken model of hypoxia-induced fetal growth retardation. Pediatr Res 2009;65:279-284.

18 Agren P, van der Sterren S, Cogolludo AL, Blanco CE, Villamor E: Developmental changes in the effects of prostaglandin $\mathrm{E}_{2}$ in the chicken ductus arteriosus. J Comp Physiol 2009;179:133-143.

19 Sutendra G, Michelakis ED: The chicken embryo as a model for ductus arteriosus developmental biology: cracking into new territory. Am J Physiol 2007;292:R481-R484.

20 Rabinovitch M, Beharry S, Bothwell T, Jackowski G: Qualitative and quantitative differences in protein synthesis comparing fetal lamb ductus arteriosus endothelium and smooth muscle with cells from adjacent vascular sites. Dev Biol 1988;130:250-258.
21 Clyman RI, Chan CY, Mauray F, Chen YQ, Cox W, Seidner SR, Lord EM, Weiss H, Waleh N, Evans SM, Koch CJ: Permanent anatomic closure of the ductus arteriosus in newborn baboons: the roles of postnatal constriction, hypoxia, and gestation. Pediatr Res 1999;45:19-29.

22 Gittenberger-de Groot AC, van Ertbruggen I, Moulaert AJ, Harinck E: The ductus arteriosus in the preterm infant: histologic and clinical observations. J Pediatr 1980;96:88-93.

23 Clyman RI, Seidner SR, Kajino H, Roman C, Koch CJ, Ferrara N, Waleh N, Mauray F, Chen YQ, Perkett EA, Quinn T: VEGF regulates remodeling during permanent anatomic closure of the ductus arteriosus. Am J Physiol 2002;282:R199-R206.

-24 Weber SC, Rheinlaender C, Sarioglu N, Peiser C, Rudiger M, Obladen M, Koehne PS: The expression of VEGF and its receptors in the human ductus arteriosus. Pediatr Res 2008;64:340-345.

25 Heymann MA, Rudolph AM: Control of the ductus arteriosus. Physiol Rev 1975;55:6278.

26 Coceani F, Olley PM, Bodach E: Lamb ductus arteriosus: effect of prostaglandin synthesis inhibitors on the muscle tone and the response to prostaglandin $\mathrm{E}_{2}$. Prostaglandins 1975;9:299-308.

27 Clyman RI: Mechanisms regulating the ductus arteriosus. Biol Neonate 2006;89:330335 .

28 Coggins KG, Latour A, Ngyuen MS, Audoly L, Coffman TM, Koller BH: Metabolism of $\mathrm{PGE}_{2}$ by prostaglandin dehydrogenase is essential for remodeling the ductus arteriosus. Nat Med 2002;8:91-92.

-29 Leonhardt A, Glaser A, Wegmann M, Schranz D, Seyberth H, Nusing R: Expression of prostanoid receptors in human ductus arteriosus. Br J Pharmacol 2003;138: 655-659.

- 30 Rheinlaender C, Weber SC, Sarioglu N, Strauss E, Obladen M, Koehne P: Changing expression of cyclooxygenases and prostaglandin receptor EP4 during development of the human ductus arteriosus. Pediatr Res 2006;60:270-275. 
-31 Ben-David Y, Hallak M, Rotschild A, Sorokin Y, Auslender R, Abramovici H: Indomethacin and fetal ductus arteriosus: complete closure after cessation of prolonged therapeutic course. Fetal Diagn Ther 1996; 11:341-344.

- 32 Hammerman C, Glaser J, Kaplan M, Schimmel MS, Ferber B, Eidelman AI: Indomethacin tocolysis increases postnatal patent ductus arteriosus severity. Pediatrics 1998;102: E56.

- 33 Michelakis ED, Rebeyka I, Wu X, Nsair A, Thébaud B, Hashimoto K, Dyck JR, Haromy A, Harry G, Barr A, Archer SL: $\mathrm{O}_{2}$ sensing in the human ductus arteriosus: regulation of voltage-gated $\mathrm{K}^{+}$channels in smooth muscle cells by a mitochondrial redox sensor. Circ Res 2002;91:478-486.

- 34 Bustamante SA, Pang Y, Romero S, Pierce MR, Voelker CA, Thompson JH, Sandoval M, Liu X, Miller MJ: Inducible nitric oxide synthase and the regulation of central vessel caliber in the fetal rat. Circulation 1996;94: 1948-1953.

- 35 Baragatti B, Brizzi F, Barogi S, Laubach VE, Sodini D, Shesely EG, Regan RF, Coceani F: Interactions between $\mathrm{NO}, \mathrm{CO}$ and an endothelium-derived hyperpolarizing factor in maintaining patency of the ductus arteriosus in the mouse. Br J Pharmacol 2007;151: $54-62$.

36 Momma K, Toyono M: The role of nitric oxide in dilating the fetal ductus arteriosus in rats. Pediatr Res 1999;46:311-315.

37 Coceani F, Barogi S, Brizzi F, Ackerley C, Seidlitz E, Kelsey L, Ballou LR, Baragatti B: Cyclooxygenase isoenzymes and patency of ductus arteriosus. Prostaglandins Leukot Essent Fatty Acids 2005;72:71-77.

-38 Sodini D, Baragatti B, Barogi S, Laubach VE, Coceani $\mathrm{F}$ : Indomethacin promotes nitric oxide function in the ductus arteriosus in the mouse. Br J Pharmacol 2008;153:1631-1640.

-39 Kajimoto H, Hashimoto K, Bonnet SN, Haromy A, Harry G, Moudgil R, Nakanishi T, Rebeyka I, Thebaud B, Michelakis ED, Archer SL: Oxygen activates the Rho/Rho-kinase pathway and induces RhoB and ROCK1 expression in human and rabbit ductus arteriosus by increasing mitochondria-derived reactive oxygen species: a newly recognized mechanism for sustaining ductal constriction. Circulation 2007;115:1777-1788.

-40 Archer SL, Michelakis ED, Thébaud B, Bonnet S, Moudgil R, Wu XC, Weir EK: A central role for oxygen-sensitive $\mathrm{K}^{+}$channels and mitochondria in the specialized oxygensensing system. Novartis Found Symp 2006; 272:157-171, discussion 171-175, 214-217.

-41 Tristani-Firouzi M, Reeve HL, Tolarova S, Weir EK, Archer SL: Oxygen-induced constriction of rabbit ductus arteriosus occurs via inhibition of a 4-aminopyridine-, voltage-sensitive potassium channel. J Clin Invest 1996;98:1959-1965.
42 Coceani F, Armstrong C, Kelsey L: Endothelin is a potent constrictor of the lamb ductus arteriosus. Can J Physiol Pharmacol 1989;67: 902-904.

43 Coceani F, Kelsey L, Ackerley C, Rabinovitch M, Gelboin H: Cytochrome P450 during ontogenic development: occurrence in the ductus arteriosus and other tissues. Can J Physiol Pharmacol 1994;72:217-226.

-44 Fineman JR, Takahashi Y, Roman C, Clyman RI: Endothelin-receptor blockade does not alter closure of the ductus arteriosus. Am J Physiol 1998;275:H1620-H1626.

45 Momma K, Nakanishi T, Imamura S: Inhibition of in vivo constriction of fetal ductus arteriosus by endothelin receptor blockade in rats. Pediatr Res 2003;53:479-485.

46 Coceani F, Liu YA, Seidlitz E, Kelsey L, Kuwaki T, Ackerley C, Yanagisawa M: Deletion of the endothelin-A-receptor suppresses oxygen-induced constriction but not postnatal closure of the ductus arteriosus. J Cardiovasc Pharmacol 2000;36:S75-S77.

47 Archer SL, Wu XC, Thebaud B, Moudgil R, Hashimoto K, Michelakis ED: $\mathrm{O}_{2}$ sensing in the human ductus arteriosus: redox-sensitive $\mathrm{K}^{+}$channels are regulated by mitochondria-derived hydrogen peroxide. Biol Chem 2004;385:205-216.

48 Hong Z, Hong F, Olschewski A, Cabrera JA, Varghese A, Nelson DP, Weir EK: Role of store-operated calcium channels and calcium sensitization in normoxic contraction of the ductus arteriosus. Circulation 2006;114: 1372-1379.

49 Costa M, Barogi S, Socci ND, Angeloni D, Maffei M, Baragatti B, Chiellini C, Grasso E, Coceani F: Gene expression in ductus arteriosus and aorta: comparison of birth and oxygen effects. Physiol Genomics 2006;25: 250-262.

50 Taussig HB: World survey of the common cardiac malformations: developmental error or genetic variant? Am J Cardiol 1982;50: 544-559.

51 Patterson DF: Epidemiologic and genetic studies of congenital heart disease in the dog. Circ Res 1968;23:171-202.

-52 Patterson DF, Pyle RL, Buchanan JW, Trautvetter E, Abt DA: Hereditary patent ductus arteriosus and its sequelae in the dog. Circ Res 1971;29:1-13.

- 53 De Reeder EG, Gittenberger-de Groot AC, van Munsteren JC, Poelmann RE, Patterson DF, Keirse MJ: Distribution of prostacyclin synthase, 6-keto-prostaglandin $F_{1} \alpha$, and 15hydroxy-prostaglandin dehydrogenase in the normal and persistent ductus arteriosus of the dog. Am J Pathol 1989;135:881-887.

54 Behmoaras J, Osborne-Pellegrin M, Gauguier D, Jacob MP: Characteristics of the aortic elastic network and related phenotypes in seven inbred rat strains. Am J Physiol 2005; 288:H769-H777.

$\checkmark 55$ Capdeville M, Coutard M, Osborne-Pellegrin MJ: Spontaneous rupture of the internal elastic lamina in the rat: the manifestation of a genetically determined factor which may be linked to vascular fragility. Blood Vessels 1989;26:197-212.
56 Gittenberger-de Groot AC, DeRuiter MC, Bergwerff M, Poelmann RE: Smooth muscle cell origin and its relation to heterogeneity in development and disease. Arterioscler Thromb Vasc Biol 1999;19:1589-1594.

57 Hirschi KK, Majesky MW: Smooth muscle stem cells. Anat Rec A Discov Mol Cell Evol Biol 2004;276:22-33.

-58 DeRuiter MC, Poelmann RE, VanMunsteren JC, Mironov V, Markwald RR, Gittenbergerde Groot AC: Embryonic endothelial cells transdifferentiate into mesenchymal cells expressing smooth muscle actins in vivo and in vitro. Circ Res 1997;80:444-451.

59 Kota L, Osborne-Pellegrin M, Schulz H, Behmoaras J, Coutard M, Gong M, Hubner $\mathrm{N}$ : Quantitative genetic basis of arterial phenotypes in the Brown Norway rat. Physiol Genomics 2007.

60 Baragatti B, Sodini D, Uematsu S, Coceani F: Role of microsomal prostaglandin E synthase-1 (mPGES1)-derived $\mathrm{PGE}_{2}$ in patency of the ductus arteriosus in the mouse. Pediatr Res 2008;64:523-527.

-61 Loftin CD, Trivedi DB, Tiano HF, Clark JA, Lee CA, Epstein JA, Morham SG, Breyer MD, Nguyen M, Hawkins BM, Goulet JL, Smithies O, Koller BH, Langenbach R: Failure of ductus arteriosus closure and remodeling in neonatal mice deficient in cyclooxygenase-1 and cyclooxygenase-2. Proc Natl Acad Sci USA 2001;98:1059-1064.

62 Nguyen M, Camenisch T, Snouwaert JN, Hicks E, Coffman TM, Anderson PA, Malouf NN, Koller BH: The prostaglandin receptor EP4 triggers remodelling of the cardiovascular system at birth. Nature 1997; 390:78-81.

63 Yokoyama U, Minamisawa S, Quan H, Ghatak S, Akaike T, Segi-Nishida E, Iwasaki S, Iwamoto M, Misra S, Tamura K, Hori H, Yokota S, Toole BP, Sugimoto Y, Ishikawa Y: Chronic activation of the prostaglandin receptor EP4 promotes hyaluronan-mediated neointimal formation in the ductus arteriosus. J Clin Invest 2006;116:3026-3034.

64 Trivedi DB, Sugimoto Y, Loftin CD: Attenuated cyclooxygenase-2 expression contributes to patent ductus arteriosus in preterm mice. Pediatr Res 2006;60:669-674.

65 Yu Y, Funk CD: A novel genetic model of selective COX-2 inhibition: comparison with COX-2 null mice. Prostaglandins Other Lipid Mediat 2007;82:77-84.

66 Baragatti B, Brizzi F, Ackerley C, Barogi S, Ballou LR, Coceani F: Cyclooxygenase-1 and -2 in the mouse ductus arteriosus: individual activity and functional coupling with nitric oxide synthase. Br J Pharmacol 2003;139: 1505-1515.

67 Yu Y, Fan J, Chen XS, Wang D, Klein-Szanto AJ, Campbell RL, FitzGerald GA, Funk CD: Genetic model of selective COX2 inhibition reveals novel heterodimer signaling. Nat Med 2006;12:699-704. 
-68 Segi E, Sugimoto Y, Yamasaki A, Aze Y, Oida $\mathrm{H}$, Nishimura T, Murata T, Matsuoka T, Ushikubi F, Hirose M, Tanaka T, Yoshida N, Narumiya S, Ichikawa A: Patent ductus arteriosus and neonatal death in prostaglandin receptor EP4-deficient mice. Biochem Biophys Res Commun 1998;246:7-12.

-69 Morano I, Chai GX, Baltas LG, LamounierZepter V, Lutsch G, Kott M, Haase H, Bader M: Smooth-muscle contraction without smooth-muscle myosin. Nat Cell Biol 2000; 2:371-375.

-70 Moser M, Pscherer A, Roth C, Becker J, Mucher G, Zerres K, Dixkens C, Weis J, Guay-Woodford L, Buettner R, Fassler R: Enhanced apoptotic cell death of renal epithelial cells in mice lacking transcription factor AP-2 $\beta$. Genes Dev 1997;11:19381948.

71 Ivey KN, Sutcliffe D, Richardson J, Clyman RI, Garcia JA, Srivastava D: Transcriptional regulation during development of the ductus arteriosus. Circ Res 2008;103:388-395.

72 Huang J, Cheng L, Li J, Chen M, Zhou D, Lu MM, Proweller A, Epstein JA, Parmacek MS: Myocardin regulates expression of contractile genes in smooth muscle cells and is required for closure of the ductus arteriosus in mice. J Clin Invest 2008;118:515-525.

73 Thebaud B, Michelakis ED, Wu XC, Moudgil R, Kuzyk M, Dyck JR, Harry G, Hashimoto K, Haromy A, Rebeyka I, Archer SL: Oxygen-sensitive $K_{v}$ channel gene transfer confers oxygen responsiveness to preterm rabbit and remodeled human ductus arteriosus: implications for infants with patent ductus arteriosus. Circulation 2004;110:13721379.

-74 Mason CA, Bigras JL, O’Blenes SB, Zhou B, McIntyre B, Nakamura N, Kaneda Y, Rabinovitch $\mathrm{M}$ : Gene transfer in utero biologically engineers a patent ductus arteriosus in lambs by arresting fibronectin-dependent neointimal formation. Nat Med 1999;5:176182.

-75 Humpl T, Zaidi SH, Coe JY, Russell J, Kaneda Y, Massaeli H, Benson LN, Rabinovitch M: Gene transfer of prostaglandin synthase maintains patency of the newborn lamb arterial duct. Pediatr Res 2005;58:976-980.

-76 Issekutz KA, Graham JM Jr, Prasad C, Smith IM, Blake KD: An epidemiological analysis of CHARGE syndrome: preliminary results from a Canadian study. Am J Med Genet A 2005;133A:309-317.

-77 Hills C, Moller JH, Finkelstein M, Lohr J, Schimmenti L: Cri du chat syndrome and congenital heart disease: a review of previously reported cases and presentation of an additional 21 cases from the Pediatric Cardiac Care Consortium. Pediatrics 2006;117: e924-927.

-78 Marino B, Digilio MC, Toscano A, Giannotti A, Dallapiccola B: Congenital heart diseases in children with Noonan syndrome: an expanded cardiac spectrum with high prevalence of atrioventricular canal. J Pediatr 1999;135:703-706.
79 Sletten LJ, Pierpont ME: Variation in severity of cardiac disease in Holt-Oram syndrome. Am J Med Genet 1996;65:128-132.

80 Satoda M, Zhao F, Diaz GA, Burn J, Goodship J, Davidson HR, Pierpont ME, Gelb BD: Mutations in TFAP2B cause Char syndrome, a familial form of patent ductus arteriosus. Nat Genet 2000;25:42-46.

81 Zhao F, Weismann CG, Satoda M, Pierpont ME, Sweeney E, Thompson EM, Gelb BD Novel TFAP2B mutations that cause Char syndrome provide a genotype-phenotype correlation. Am J Hum Genet 2001;69:695703.

82 Pyeritz RE, Murphy EA, McKusick VA: Clinical variability in the Marfan syndrome(s). Birth Defects Orig Artic Ser 1979; 15:155-178.

$\$ 83$ Loeys BL, Schwarze U, Holm T, Callewaert BL, Thomas GH, Pannu H, De Backer JF, Oswald GL, Symoens S, Manouvrier S, Roberts AE, Faravelli F, Greco MA, Pyeritz RE, Milewicz DM, Coucke PJ, Cameron DE, Braverman AC, Byers PH, De Paepe AM, Dietz HC: Aneurysm syndromes caused by mutations in the TGF- $\beta$ receptor. N Engl J Med 2006; 355:788-798.

84 Kiel EA, Frias JL, Victorica BE: Cardiovascular manifestations in the Larsen syndrome. Pediatrics 1983;71:942-946.

85 Pepin M, Schwarze U, Superti-Furga A, Byers PH: Clinical and genetic features of Ehlers-Danlos syndrome type IV, the vascular type. N Engl J Med 2000;342:673-680.

86 Zhu L, Vranckx R, Khau van Kien P, Lalande A, Boisset N, Mathieu F, Wegman M, Glancy L, Gasc JM, Brunotte F, Bruneval P, Wolf JE Michel JB, Jeunemaitre X: Mutations in myosin heavy chain 11 cause a syndrome associating thoracic aortic aneurysm/aortic dissection and patent ductus arteriosus. Nat Genet 2006;38:343-349.

87 Guo DC, Pannu H, Tran-Fadulu V, Papke CL, Yu RK, Avidan N, Bourgeois S, Estrera AL, Safi HJ, Sparks E, Amor D, Ades L, McConnell V, Willoughby CE, Abuelo D, Willing $M$, Lewis RA, Kim DH, Scherer S, Tung PP, Ahn C, Buja LM, Raman CS, Shete SS Milewicz DM: Mutations in smooth muscle $\alpha$-actin (ACTA2) lead to thoracic aortic aneurysms and dissections. Nat Genet 2007;39: 1488-1493.

88 Lund JT, Jensen MB, Hjelms E: Aneurysm of the ductus arteriosus. A review of the literature and the surgical implications. Eur J Cardiothorac Surg 1991;5:566-570.

89 Acherman RJ, Siassi B, Wells W, Goodwin M, DeVore G, Sardesai S, Wong PC, Ebrahimi M, Pratti-Madrid G, Castillo W, Ramanathan R: Aneurysm of the ductus arteriosus: a congenital lesion. Am J Perinatol 1998; 15: 653-659.

90 Dyamenahalli U, Smallhorn JF, Geva T, Fouron JC, Cairns P, Jutras L, Hughes V, Rabinovitch M, Mason CA, Hornberger LK: Isolated ductus arteriosus aneurysm in the fetus and infant: a multi-institutional experience. J Am Coll Cardiol 2000;36:262-269.
91 Mielke G, Benda N: Reference ranges for two-dimensional echocardiographic examination of the fetal ductus arteriosus. Ultrasound Obstet Gynecol 2000;15:219225.

92 Matt P, Habashi J, Carrel T, Cameron DE, Van Eyk JE, Dietz HC: Recent advances in understanding Marfan syndrome: should we now treat surgical patients with losartan? J Thorac Cardiovasc Surg 2008; 135: 389-394.

93 Zhou B, Coulber C, Rabinovitch M: Tissuespecific and developmental regulation of transforming growth factor- $\beta_{1}$ expression in fetal lamb ductus arteriosus endothelial cells. Pediatr Res 1998;44:865-872.

94 Tannenbaum JE, Waleh NS, Mauray F, Breuss J, Pytela R, Kramer RH, Clyman RI: Transforming growth factor- $\beta_{1}$ inhibits fetal lamb ductus arteriosus smooth muscle cell migration. Pediatr Res 1995;37:561570 .

-95 Tannenbaum JE, Waleh NS, Mauray F, Gold L, Perkett EA, Clyman RI: Transforming growth factor- $\beta$ protein and messenger RNA expression is increased in the closing ductus arteriosus. Pediatr Res 1996;39: 427-434.

-96 Boudreau N, Clausell N, Boyle J, Rabinovitch M: Transforming growth factor- $\beta$ regulates increased ductus arteriosus endothelial glycosaminoglycan synthesis and a post-transcriptional mechanism controls increased smooth muscle fibronectin, features associated with intimal proliferation. Lab Invest 1992;67:350-359.

-97 Qiu P, Ritchie RP, Fu Z, Cao D, Cumming J, Miano JM, Wang DZ, Li HJ, Li L: Myocardin enhances Smad3-mediated transforming growth factor- $\beta_{1}$ signaling in a CArG box-independent manner: Smad-binding element is an important cis element for SM22 $\alpha$ transcription in vivo. Circ Res 2005;97:983-991.

-98 Khau van Kien P, Mathieu F, Zhu L, Lalande A, Betard C, Lathrop M, Brunotte F, Wolf JE, Jeunemaitre X: Mapping of familial thoracic aortic aneurysm/dissection with patent ductus arteriosus to $16 \mathrm{p} 12.2$ p13.13. Circulation 2005;112:200-206.

$\checkmark 9$ Mani A, Meraji SM, Houshyar R, Radhakrishnan J, Mani A, Ahangar M, Rezaie TM, Taghavinejad MA, Broumand B, Zhao H, Nelson-Williams C, Lifton RP: Finding genetic contributions to sporadic disease: a recessive locus at 12 q 24 commonly contributes to patent ductus arteriosus. Proc Natl Acad Sci USA 2002;99:15054-15059.

100 Schulz RA, Yutzey KE: Calcineurin signaling and NFAT activation in cardiovascular and skeletal muscle development. Dev Biol 2004;266:1-16.

101 Iwasaki S, Minamisawa S, Yokoyama U, Akaike T, Quan H, Nagashima Y, Nishimaki S, Ishikawa Y, Yokota S: Interleukin-15 inhibits smooth muscle cell proliferation and hyaluronan production in rat ductus arteriosus. Pediatr Res 2007;62:392-398. 